\title{
Effects of the parasite Probopyrus ringueleti (Isopoda) on glucose, glycogen and lipid concen- tration in starved Palaemonetes argentinus (Decapoda)
}

\author{
Carla Amorim Neves ${ }^{1}$, Maria Paz Sampedro Pastor ${ }^{2}$, Luiz Eduardo Maia Nery ${ }^{1}$, \\ Euclydes A. Santos ${ }^{1, *}$
}

${ }^{1}$ Laboratório de Zoofisiologia, Departamento de Ciências Fisiológicas, Fundação Universidade Federal do Rio Grande, Cx. Postal 474, CEP96201900, Rio Grande RS, Brazil

${ }^{2}$ Centro Oceanográfico de A Coruña, Muelle de Ánimas s/n, 15001 A Coruña, Spain

\begin{abstract}
Effects of the branchial ectoparasite isopod Probopyrus ringueleti on the utilization of glucose, glycogen and total lipids on starved shrimp Palaemonetes argentinus were evaluated, as well as the isopod responses to host starvation. Shrimp were maintained for $12 \mathrm{~d}$ under laboratory conditions. Parasitized and unparasitized shrimp were starved for $15 \mathrm{~d}$, and glucose, glycogen and total lipid concentrations were determined at 0, 24, 72, 168 and $360 \mathrm{~h}$ of starvation. During starvation, control animals (unparasitized) preferentially metabolized lipids and preserved their carbohydrate reserves. Parasitized shrimp had lower lipid concentrations than unparasitized shrimp, and preferentially metabolized carbohydrates. Bopyrids displayed a similar response, with glycogen depleted at the beginning of the starvation period followed by subsequent reestablishment. Our results demonstrated that bopyrids affect host energy allocation. The lower initial lipid concentration of parasitized shrimp suggested that the host is disadvantaged from both food deprivation and isopod nutritional demands. A possible dependency of $P$. ringueleti on the mechanisms that control host metabolic processes was also suggested.
\end{abstract}

KEY WORDS: Palaemonetes $\cdot$ Probopyrus $\cdot$ Parasitism $\cdot$ Carbohydrates $\cdot$ Lipids $\cdot$ Starvation

\section{INTRODUCTION}

Nutritional deprivation is a natural part of the life cycle of many aquatic organisms and results from winter torpor, seasonal variation of food availability, behavioral modifications during mating/spawning (Schirf et al. 1987) and also parasitism (Walkey \& Meakins 1970, Astete-Espinosa \& Caceres 2000). Most species reduce their metabolic rate and deplete protein, carbohydrate, glycogen and/or lipid reserves during nutritional stress (Hazlett et al. 1975, Regnault 1981). The relative importance of these energetic reserves and the order of utilization vary with species, recent feeding history and length of starvation (Schirf et al. 1987, Moon 1988).
Parasitism can influence the re-allocation of host energetic reserves (Plaistow et al. 2001). Gammarus pulex infected by the acanthocephalan Pomphorhynchus laevis had significantly lower lipid and higher glycogen concentrations than unparasitized individuals (Plaistow et al. 2001). Also, the ghost shrimp Neotrypaea uncinata parasitized by the bopyrid Ionella agassizi had a higher hemolymphatic glucose concentration and a reduction of protein and total lipid concentration in comparison to unparasitized organisms (Astete-Espinoza \& Caceres 2000). Hematodinium sp., a dinoflagellate parasite of Nephrops norvegicus, may induce a reduction of hemolymphatic glucose followed by a significantly lower concentration 
of hepatopancreatic glycogen and glucose in the hemolymph in advanced stages of infection (Stentiford et al. 2001).

Palaemonetes argentinus is a caridean shrimp found at Patos Lagoon estuary (southern Brazil) and is parasitized by the isopod Probopyrus ringueleti. In this highly variable environment, it is known to regularly face variations in biological, chemical and physical parameters, including food availability. Few data are available regarding the effects of parasitism on hostreserve mobilization during energetic deprivation and/or expenditure, and also regarding the parasite's energetic reserves during host starvation.

Therefore, considering the above facts, as well as the information that bopyrid isopods can consume up to $80 \mathrm{\mu l} \mathrm{d}^{-1}$ of host hemolymph (Walker 1977), our aim was to study how parasitism by Probopyrus ringueleti affects energetic reserve utilization by $P$. argentinus during starvation, through determinations of glucose, glycogen and total lipid concentrations. This work also aimed to verify, for the first time, the effects of host starvation on bopyrid energetic reserves.

\section{MATERIALS AND METHODS}

Adult intermolt Palaemonetes argentinus, both unparasitized and parasitized by the isopod Probopyrus ringueleti, were collected from the Patos Lagoon estuary (southern Brazil) and acclimated for $12 \mathrm{~d}$ in the laboratory in a $60 \mathrm{l}$ aquarium at $10 \mathrm{ppt}$ salinity and $20 \pm$ $1^{\circ} \mathrm{C}$. They were fed ad libitum with ground beef every 2 d. Each parasitized shrimp was infected with only 2 isopods in one side of the branchial chamber.

Experimental groups included (1) unparasitized shrimp (controls), (2) parasitized shrimp (with mature isopods in one side of the branchial chamber; these shrimp were deparasitized before chemical determinations), and (3) isopods (female isopod isolated from its host and separated from its dwarf male, before each determination). Shrimp were weighted (wet weight) and sex was determined. Carbohydrates (glucose and glycogen) and total lipid concentrations for whole Palaemonetes argentinus plus parasites were assayed at the beginning of the starvation period (Time 0), and again after $24,72,168$, and $360 \mathrm{~h}$ starvation, between 09:00 and 11:00 h.

Shrimp and isopods were macerated with sodium citrate $(100 \mathrm{mM})$. Glucose was determined by the glucose-oxidase method (kits from Doles Reagentes \& Equipamentos). Glycogen concentrations were determined as suggested by Carr \& Neff (1984), and modified by Nery \& Santos (1993). Shrimp and isopods were macerated with chloroform/ethanol $(2: 1 \mathrm{v} / \mathrm{v})$, aliquots were removed, and lipid concentration determined fol- lowing the sulfuphosphovanillin method (kits from Doles Reag. \& Equip). Concentrations are expressed as $\mathrm{mg} \mathrm{g}^{-1}$.

Data were analyzed using ANOVA, and when necessary, mathematical transformations were applied to normalize the data (Shapiro Wilks' test) and carry out homogeneity of variances (Levene's test). ANOVA was followed by Tukey's HSD test for multiple comparison of means. Possible effects of sex were analyzed by Student's $t$-test, and when no significant differences $(p>0.05)$ were found, male and female data were pooled. All tests were run on Statistica for Windows (v. 5.1 B, SatSoft). Data are expressed as means \pm SE.

\section{RESULTS}

\section{Sexual differences}

No significant differences $(\mathrm{p}>0.05)$ in the effects of Probopyrus ringueleti were found between sexes in any group, except that the glucose concentration of unparasitized shrimp was higher $(p<0.05)$ for males than for females. Consequently, in this group (glucose concentration of unparasitized shrimp) ANOVA was performed separately by sex. The isopods did not show differences in their reserves with relation to host sex ( $p>0.05)$.

\section{Effect of parasitism in fed Palaemonetes argentinus}

Parasitized shrimp at Time 0 had a significantly higher $(\mathrm{p}<0.05)$ initial glycogen concentration $(2.60 \pm$ $\left.0.51 \mathrm{mg} \mathrm{g}^{-1}\right)$ and a significantly $(\mathrm{p}<0.05)$ lower concentration of lipids $\left(3.22 \pm 0.63 \mathrm{mg} \mathrm{g}^{-1}\right)$ than non-parasitized shrimp $\left(1.15 \pm 0.23\right.$ and $6.59 \pm 0.61 \mathrm{mg} \mathrm{g}^{-1}$, respectively). The initial concentration of total lipids in parasitized shrimp was near the concentration in unparasitized individuals at the end of $15 \mathrm{~d}$ starvation $\left(2.98 \mathrm{mg} \mathrm{g}^{-1}\right)$. The proportion between carbohydrate (glucose plus glycogen) and total lipids was similar in parasitized shrimp and isopods.

\section{Starved unparasitized Palaemonetes argentinus}

During the starvation period, no significant differences were observed for glucose concentrations in unparasitized females or males $(p>0.05)$ (means \pm SE pooled and plotted in Fig. 1A) .Glycogen concentration did not vary either during the starvation period $(\mathrm{p}>$ 0.05) (Fig. 1B), while total lipids decreased significantly from $6.59 \pm 0.61$ to $2.24 \pm 0.15 \mathrm{mg} \mathrm{g}^{-1}$ in the first $24 \mathrm{~h}(\mathrm{p}<0.05)$, and remained low until the end of the experimental period (Fig. 1C). 

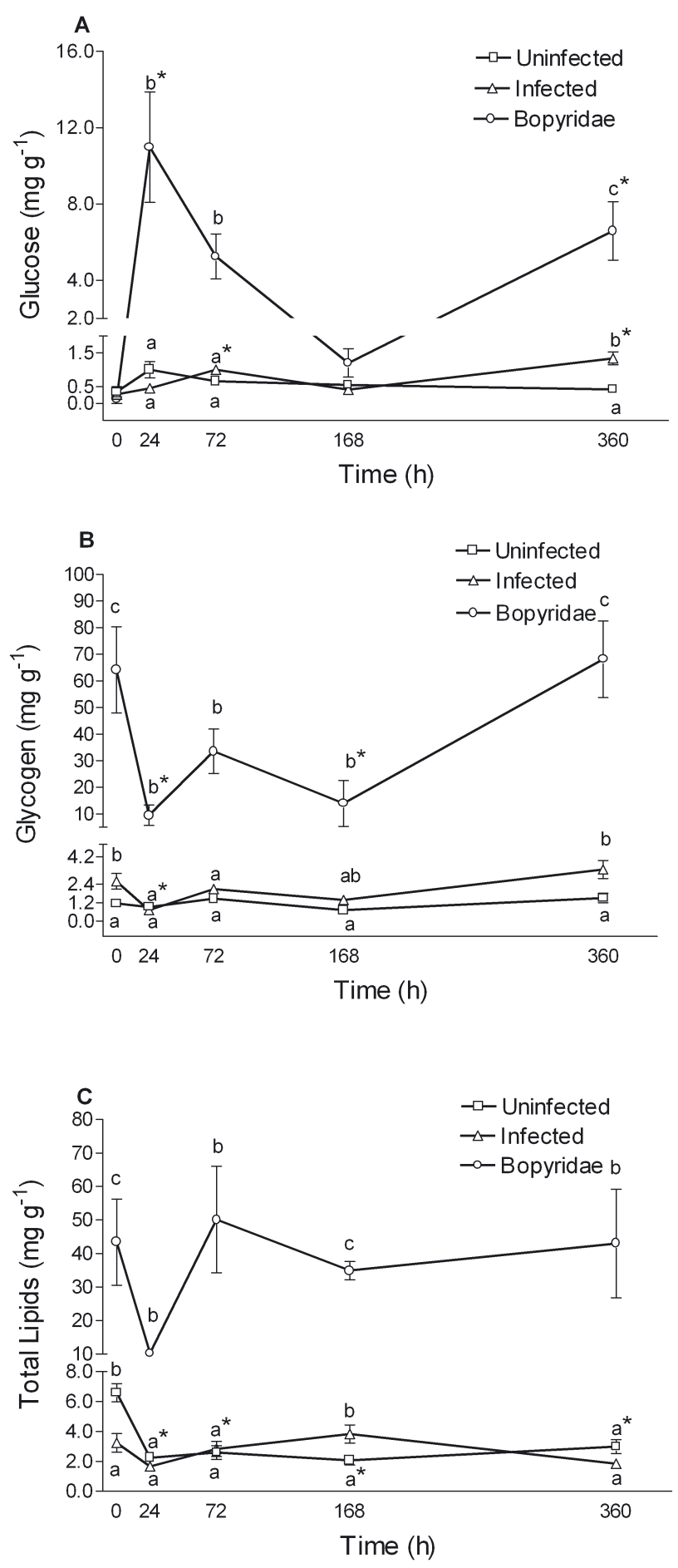

Fig. 1. Palaemonetes argentinus parasitized by Probopyrus ringueleti. Variation in glucose, glycogen and total lipid concentrations (mean $\pm \mathrm{SE}$ ) in normal $P$. argentinus shrimp parasitized by $P$. ringueleti and in the parasite, during $360 \mathrm{~h}$ of starvation. (A) Glucose concentration $\left(\mathrm{mg} \mathrm{g}^{-1}\right)$; (B) glycogen concentration $\left(\mathrm{mg} \mathrm{g}^{-1}\right)$; (C) total lipid concentration $\left(\mathrm{mg} \mathrm{g}^{-1}\right)$. Letters indicate values not significantly different (inter-group comparison) (ANOVA, $\mathrm{p}>0.05)$, *: values significantly different at Time 0 (ANOVA, $\mathrm{p}<0.05$ ). ( $\mathrm{n}=7$ to 10 parasitized shrimp; $\mathrm{n}=9$ to 20 unparasitized shrimp; $\mathrm{n}=6$ to 10 isopods)

\section{Starved parasitized Palaemonetes argentinus}

During starvation, glucose concentration oscillated and increased significantly $(p<0.05)(0.99 \pm 0.13$ and $1.34 \pm 0.19 \mathrm{mg} \mathrm{g}^{-1}$ at 72 and $360 \mathrm{~h}$, respectively) (Fig. 1A). Glycogen concentration decreased significantly $(p<0.05)$ at the beginning of the starvation period $\left(0.72 \pm 0.11 \mathrm{mg} \mathrm{g}^{-1}\right.$ after $\left.24 \mathrm{~h}\right)$, returning thereafter to initial values $\left(2.60 \pm 0.51 \mathrm{mg} \mathrm{g}^{-1}\right)$ (Fig. 1B). Total lipids after $24 \mathrm{~h}$ starvation $\left(1.65 \pm 0.27 \mathrm{mg} \mathrm{g}^{-1}\right)$ were significantly lower $(\mathrm{p}<0.05)$ than at $168 \mathrm{~h}(3.83 \pm 0.61 \mathrm{mg}$ $\left.\mathrm{g}^{-1}\right)$, but there was no significant difference between these and the initial values $\left(3.22 \pm 0.63 \mathrm{mg} \mathrm{g}^{-1}\right.$ ) (Fig. 1C).

\section{Effects of host starvation on Probopyrus ringueleti}

Glucose concentration significantly increased $(\mathrm{p}<$ 0.05 ) from a minimal of $0.15 \pm 0.15 \mathrm{mg} \mathrm{g}^{-1}$ at the beginning of the experiment to a maximum of $10.98 \pm$ $2.89 \mathrm{mg} \mathrm{g}^{-1}$ (after $24 \mathrm{~h}$ ) (Fig. 1A). Glycogen concentration (Fig. 1B) decreased significantly $(p<0.05)$ at 24 and $168 \mathrm{~h}$ (from $64.19 \pm 16.21$ to $9.53 \pm 3.81$ and $13.9 \pm$ $8.59 \mathrm{mg} \mathrm{g}^{-1}$, respectively), but the initial values were restored by the end of the experiment. Total lipids did not vary significantly $(p>0.05)$.

\section{DISCUSSION}

Parasitized Palaemonetes argentinus had significantly $(p<0.05$ ) lower concentrations of lipid and higher concentrations of glycogen than unparasitized shrimp. In another study, the ghost shrimp Neotrypaea uncinata parasitized by the bopyrid Ionella agassizi showed a reduction of hemolimphatic protein and hemocyanin, lactate and total lipids, and a concomitant increase of glucose concentration (Astete-Espinoza \& Caceres 2000). Working with Gammarus pulex parasitized by acanthocephalans, Plaistow et al. (2001) found that parasitized gravid females had a significantly lower lipid concentration than unparasitized gravid females, and also found an increase in glycogen of parasitized gammarids, independent of sex or reproductive status. Artemia spp. parasitized by cestodes also showed an increase in glycogen concentration, according to Amat et al. (1991). However, Nephrops norvegicus, when parasitized by the dinoflagellate Hematodinium sp., showed a reduction in glucose (from the hemolymph) and glycogen content (from the hepatopancreas), and a significant increase in the crustacean hyperglycemic hormone $(\mathrm{CHH})$ during the patent stages of infection (Stentiford et al. 2001). Data comparisons with the previous literature are difficult, 
since most information is related to endoparasitic trematodes. The life history of these parasites is quite different from that of an ectoparasite, and especially from non-helminthes. If the isopod burden on host reserves is more pronounced for lipids, especially due to energetic demands for parasite reproduction, the increase in host glycogen reserves might have evolved as a counter-adaptation to parasitism, as already proposed by Plaistow et al. (2001).

Unparasitized Palaemonetes argentinus utilized $66 \%$ of the initial lipid reserves during the first $24 \mathrm{~h}$ of starvation, without any significant recovery. Also, no significant signs of glucose or glycogen depletion could be detected. This lipid concentration decrease during starvation is in accordance with data presented by Speck \& Ulrich (1969) for Orconectes limosus, Schirf et al. (1987) for Procambarus clarkii and Moore et al. (2000) for Penaeus monodon and P. semisulcatus, confirming the general assumption that energy metabolism in crustaceans is centered around lipids (Barclay et al. 1983). Our data also suggested that lipids are the main source of energy during starvation.

Parasitized Palaemonetes argentinus showed a $72 \%$ reduction in available glycogen, but the initial values were restored thereafter. This glycogen depletion could have been responsible for the significant $(p<0.05)$ increase in glucose (after 72 and $360 \mathrm{~h}$ ). The low lipid concentration in parasitized shrimp oscillated throughout the experimental period, without significant differences ( $p>0.05)$. This low lipid concentration could represent structural components that are not readily available for use as an energetic substrate. According to Plaistow et al. (2001), a high lipid content is an indicator of good physiological condition in invertebrates, and it is clear that parasitized shrimp are at a disadvantage when starved. On the other hand, carbohydrates appear to be of great importance, because the glycogen concentration was significantly higher $(\mathrm{p}<0.05)$ in parasitized shrimp. Carbohydrate dependency in parasitized shrimp could be a reflex to the lower ability to oxidize lipids, especially considering that bopyrid isopods cause respiratory impairment to their hosts (Anderson 1975, Schuldt \& Rodrigues-Capítulo 1987, Neves et al. 2000).

Probopyrus ringueleti responded to host starvation with a similar pattern of reserve utilization as its host. Glucose increased in the first $24 \mathrm{~h}$ of host starvation and the glycogen concentration fell significantly during the same period $(85 \%)$, but was restored thereafter. Some parasitic helminthes display similar responses but without restoration of energetic reserves, except when starvation is suspended (Halton 1997). According to Walker (1977), circulating nutrients in the host may regulate the ingestion of hemolymph by ectoparasitic isopods, and the reduction in circulating nutrients could decrease parasite hemolymph ingestion and/or stimulate the utilization of their own reserves. Indeed, hormonal factors that initiate glycogenolysis or beta-oxidation pathways in hosts could have a similar metabolic effect on the parasite. In this way, isopod metabolism appears to be dependent on the processes which regulate their hosts' metabolism or, at least, they are rapidly influenced by the host hemolymphatic nutrient concentrations, as predicted by some early authors (Veillet 1945, Hartnoll 1967, Field 1969, Walker 1977). The similar pattern of reserve utilization found in isopods and their host shrimp, when the isopods have had normal access to host nutrients, suggests parasite metabolic dependency on host regulatory mechanisms.

In summary, the results demonstrate that bopyrids affect host reserve concentrations. The initial lipid concentration of parasitized shrimp was as low as that of unparasitized animals after $360 \mathrm{~h}$ of starvation. This disadvantageous energetic status of unparasitized shrimp was caused by food deprivation and isopod nutritional demands, which forced hosts to utilize mainly carbohydrate sources.

In the future, research should focus on protein concentration during starvation in order to verify whether the recovery of some substrates' concentrations, described in the present paper, could be due to protein catabolism. Also, a determination of crustacean hyperglycemic hormone concentration in both host and parasite could provide important information on the possible dependency of isopod metabolic processes on host metabolic regulation.

Acknowledgements. The authors wish to express their gratitude to CAPES (fellowship to C.A.N.), to CNPq (productivity fellowship to E.A.S., Proc. No. 300763/87-5) and to the Instituto de Cooperación Iberoamericana - Intercampus 1996 (fellowship to M.P.S.P.).

\section{LITERATURE CITED}

Amat F, Gozalbo JC, Navarro JC, Hontoria F, Varó I (1991) Some aspects of Artemia biology affected by cestode parasitism. Hydrobiologia 212:39-44

Anderson G (1975) Metabolic response of the caridean shrimp Palaemonetes pugio to infection by the adult epibranchial isopod parasite Probopyrus pandalicola. Comp Biochem Physiol A52:201-207

Astete-Espinosa L, Caceres CW (2000) Efecto del parasitismo del isópodo bopírido Ionella agassizi (Isopoda: Epicaridea) (Bornnier, 1900) sobre la fisiología nutricional del nape Neotrypaea uncinata (M. Edwards, 1837) (Decapoda: Thalassinidea). Rev Chil Hist Nat 73:243-252

Barclay MC, Dall W, Smith DM (1983) Changes in lipid and protein during starvation and the moulting cycle in the tiger prawn, Penaeus esculentus Haswell. J Exp Mar Biol Ecol 68:229-244

Carr RS, Neff JM (1984) Quantitative semi-automated enzymatic assay for tissue glycogen. Comp Biochem Physiol B 77(3):447-449 
Field LH (1969) The biology of Notophryxus lateralis (Isopoda, Epicaridea), parasitic on the euphausiid Nematoscelis difficilis. J Parasitol 55:1271-1277

Halton DW (1997) Nutritional adaptations to parasitism within the Platyhelminthes. Int J Parasitol 27(6):693-704

Hartnoll RG (1967) The effects of sacculinid parasites on two Jamaican crabs. J Linn Soc Lond Zool 46:275-296

Hazlett B, Rubenstein D, Rittschoff D (1975) Starvation, energy reserves, and aggression in the crayfish Orconectes virilis (Hagen, 1870) (Decapoda, Cambaridae). Crustac Int J Crustac Res 28(1):11-16

Moon TW (1988) Adaptation, constraint, and the function of the gluconeogenic pathway. Can J Zool 66:1059-1068

Moore LE, Smith DM, Loneragan NR (2000) Blood refractive index and whole-body lipid content as indicators of nutritional condition for penaeid prawns (Decapoda: Penaeidae). J Exp Mar Biol Ecol 244:131-143

Nery LEM, Santos EA (1993) Carbohydrate metabolism during osmoregulation in Chasmagnathus granulata Dana, 1851 (Crustacea, Decapoda). Comp Biochem Physiol B 106(3):747-753

Neves CA, Santos EA, Bainy ACD (2000) Reduced superoxide dismutase activity in Palaemonetes argentinus (Decapoda, Palaemonidae) infected by Probopyrus ringueleti (Isopoda, Bopyridae). Dis Aquat Org 39:155-158

Plaistow SJ, Troussard JP, Cézilly F (2001) The effect of acanthocephalan parasite Pomphorhynchus laevis on the lipid and glycogen content of its intermediate host Gammarus pulex. Int J Parasitol 31:346-351

Editorial responsibility: Timothy Flegel,

Bangkok, Thailand
Regnault M (1981) Respiration and ammonia excretion of the shrimp Crangon crangon L.: metabolic response to prolonged starvation. J Comp Physiol 141:549-555

Schirf VR, Turner P, Selby L, Hannapel C, De La Cruz P, Dehn PF (1987) Nutritional status and energy metabolism of crayfish (Procambarus clarkii, Girard) muscle and hepatopancreas. Comp Biochem Physiol A88(3):383-386

Schuldt M, Rodrigues-Capítulo A (1987) La infestacion de Palaemonetes (Palaemonetes) argentinus (Crustacea, Palaemonidae) con Probopyrus cf. oviformis (Crustacea, Bopyridae). I. Observaciones sobre la histopatología y fisiología branquial de los camarones. Rev Mus La Plata Sec Zool 154(XIV):65-82

Speck U, Urich K (1969) Consumption of body constituents during starvation in the crayfish Orconectes limosus. Z Vergl Physiol 63:410-414

Stentiford GD, Chang ES, Chang SA, Neil DN (2001) Carbohydrate dynamics and the crustacean hyperglycemic hormone $(\mathrm{CHH})$ : effects of parasitic infection in Norway lobsters (Nephrops norvegicus). Gen Comp Endocrinol 121: $13-22$

Walker SP (1977) Probopyrus pandalicola: discontinuous ingestion of shrimp hemolymph. Exp Parasitol 41:198-205

Walkey M, Meakins RH (1970) An attempt to balance the energy budget of a host-parasite system. J Fish Biol 2: 361-372

Veillet A (1945) Recherches sur les parasitisme des Crabes et des Galathées par les Rizocéphales et les Epicarides. Ann Inst Oceanogr 22:193-341

Submitted: May 5, 2003; Accepted: October 14, 2003 Proofs received from author(s): February 2, 2004 